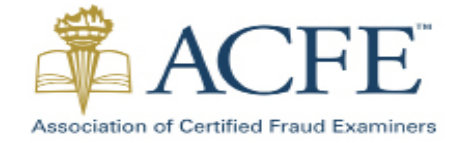

Indonesia Chapter \#111

\section{Asia Pacific Fraud Journal E-ISSN: 2502-695X, ISSN: 2502-8731 \\ Volume 5, Nomor 1 (January-June) 2020 http://apfjournal.or.id/index.php/apf}

\title{
INCIDENCE AND ROOT CAUSE OF UPCODING IN THE IMPLEMENTATION OF SOCIAL HEALTH INSURANCE IN RURAL PROVINCE HOSPITAL IN INDONESIA
}

\author{
${ }^{凶}$ Syafrawati, ${ }^{1}$ Rizanda Machmud, ${ }^{2,3}$ Syed Mohamed Aljunid, ${ }^{1}$ Rima Semiarty \\ ${ }^{1}$ Andalas University, Indonesia \\ ${ }^{2}$ National University of Malaysia, Malaysia \\ ${ }^{3}$ Kuwait University, Kuwait
}

\author{
ARTICLE INFORMATION \\ Article History: \\ Received June 17, 2019 \\ Revised July 07, 2019 \\ Accepted June 18, 2020
}

JEL Classifications:

G21; L10; P24

DOI:

10.21532/apfjournal.v5i1.135

\begin{abstract}
ABTRACT
Upcoding is one of important indicators of moral hazard and fraud in Social Health Insurance scheme. However, there seems to be little evidence about incidence of upcoding and how upcoding occurs in hospital, especially in rural province hospital. The objective of this study is to determine incidence and root cause of upcoding in the implementation of Social Health Insurance in Rural Province Hospital in Indonesia. The data used in this study were both qualitative and quantitative data (mixed method). Three hundred and sixty (360) inpatient medical records from six rural province hospitals were examined in this study. Diagnosis and procedure codes recorded in these medical records were re-coded by an independent senior coder (ISC). Codes from hospitals' coders and codes from ISC were then re-grouped using INA-CBG casemix grouper to determine the casemix groups and the hospital tariffs. If the hospital tariff obtained by hospital coder is higher than that obtained by ISC, it is considered as upcoding. This qualitative study was conducted using Focus Group Discussion (FGD) and in-depth interviews in hospitals located in a rural province of Indonesia. In depth interview was held for two hospital directors and two officers from the Social Security Administrator (Indonesia: Badan Penyelenggara Jaminan Sosial / BPJS), an agent that manages the Statutory Health Insurance (SHI). Six clinicians and six coders attended the FGD. We asked openended questions about their perceptions on upcoding in hospitals. The interviews were recorded and transcribed verbatim. The transcripts were then thematically analyzed. Upcoding cases were found in 11.9\% (43/360) medical records. Upcoding cases were dominated by Deliveries Group $2.8 \%$ (10/360) and Female reproductive system Groups 1.7\% (6/360). The potential loss of income due to upcoding was IDR 154.626 .000 or $9 \%$ of hospital revenue. Appointment of non-medical doctors as internal verifiers, lack of clear coding guidelines, lack of training for doctors and coders, and poor coordination between hospital and BPJS to resolve coding disagreement were root causes of upcoding in hospital. Policies to prevent and manage upcoding should be urgently developed and implemented in the Statutory Health Insurance (SHI) program in Indonesia especially to prepare upcoding guidelines, enhance medical coding training regularly, increase number of coders and verification staff from medical background, and strengthen coordination for coding problem solving in hospital.
\end{abstract}

Keywords: Hospital, Upcoding, Root Cause

\section{INTRODUCTION}

The National Health Insurance (NHI), or Statutory Health Insurance (SHI), which has been implemented since 2014 aims to ensure that participants benefit from health care and protection in meeting 
basic health needs. Indonesia has committed that, in the five years since its implementation precisely on January 1, 2019, the entire population of Indonesia will have participated in the National Health Insurance (NHI) so that universal coverage is achieved. (Ministry of Health, 2004)

Various obstacles faced by BPJS Health and the government in the implementation of National Health Insurance, one of which is the mismatch between BPJS Health revenues and benefit costs. This causes BPJS Health to experience deficits from year to year. In 2014 the BPJS Health deficit was IDR 3.3 trillion, in 2015 was IDR 5.7 trillion, and in 2016 was IDR 6.8 trillion (BPJS, 2016a). One of the causes of this deficit was the possibility of fraud or moral hazard that occurred at National Health Insurance providers, such as hospitals.

The types of fraud that occur in hospitals are contained in Minister of Health Regulation No. 35 of 2015 concerning Prevention of Fraud in the implementation of the National Health Insurance program in the National Health Insurance System. One type of fraud that can occur in hospitals is upcoding (Ministry of Health, 2015a).

Upcoding is changing the diagnosis code and / or procedure into a code that has a higher tariff than it should be (Ministry of Health, 2015b). Upcoding is also defined as an act of changing a patient's DiagnosisRelated Group (DRG) to another DRG which results in higher payments from third parties (Barros and Braun, 2016). According to Silverman and Skinner, DRG upcoding refers to erroneous coding that result in the shifting of a patient episode into a DRG with a higher reimbursement cost (Silverman and Skinner, 2004).

Until now there have been only a few studies that discuss the upcoding in hospitals in the National Health Insurance era. This study aims to determine the magnitude of upcoding, hospital losses due to upcoding, and the root cause of upcoding in hospitals in West Sumatra Province.

\section{METHODS}

This research used mix method by combining quantitative and qualitative data. Quantitative data were obtained from 360 inpatient medical records at 6 hospitals consisting of 3 government hospitals and 3 private hospitals. At each hospital 60 medical records were taken, and divided into 4 large casemix groups, namely surgical inpatient cases (group 1), non-procedure inpatient cases (group 4), obstetric inpatient cases (group 6), and neonatal inpatient cases (group 8).

This quantitative study used an independent senior coder (ISC) as a reviewer of the patient's medical record. Upcoding is detected by comparing diagnosis codes and procedures written by hospital coders with codes written by independent senior coders (ISC). These two codes were re-entered in the INA CBG software to see the INA CBG rates. If the INA CBG tariff is higher than the code generated by the hospital code, the medical record file is classified as up coding. Data analysis was carried out univariately and looked at the losses incurred due to upcoding.

This qualitative research used in-depth interview methods and Focus Group Discussion. In-depth interviews were conducted with two hospital directors, and two BPJS Health verifiers. FGDs were conducted on six specialist doctors and six hospital coders. The results of the study were analyzed in stages starting from processing the themes, categorizing, finding key relationships, and making maps or matrices.

\section{RESULT AND DISCUSSION}

Table 1. Upcoding Frequency Distribution

\begin{tabular}{llll}
\hline Variable & Up Coding & 43 & $11,9 \%$ \\
\hline & No Up Coding & 317 & $88,1 \%$ \\
& Total & 360 & $100 \%$ \\
\hline
\end{tabular}

Source: Primary Data

From Table 1, it can be seen that upcoding was found in $43 / 360$ medical records or $11.9 \%$. 
Table 2 shows that the largest percentage of upcoding incidents was in CMG O, namely Deliveries Group (2.8\%), followed by CMG W, namely Female Reproductive System Groups (1.7\%).

The results of the calculation of hospital losses due to upcoding are $9 \%$ of total hospital revenue.

The results of qualitative research state that the causes of upcoding can be classified in three causes: 1) related to hospitals; 2) related to doctors; and 3) related to coders. The cause of upcoding from the hospital side is that until now there has been no clear coding guidelines. The Ministry of Health has issued Minister of Health Regulation No. 76 of 2016 concerning the guidelines of the Indonesian Case-Based Groups (INA CBG) in the Implementation of National Health Insurance (Kemenkes RI, 2016b), but there is also a circular letter from the Minister of Health No. HK.03.03 / Menkes / 518/2016 concerning Guidelines for Resolving Problems of INA
CBG Claims in organizing National Health Insurance, and Cover Letter of Minutes of Agreement with the Guidelines for the Implementation of Solution for INA CBG Claim Problems from BPJS Health. According to the informant, there are some changes in the new rules compared to the previous rules. For example, initially a urinary tract infection (UTI) disease may be coded as a diagnosis, but after there is a new regulation the UTI that can be coded is a UTI caused by stones in the urinary tract. Likewise with anemia, initally anemia may be coded as a diagnosis, but in the new rule anemia can only be coded if blood transfusion is needed. These changes make ambiguous boundaries about upcoding. Hospitals may unintentionally conduct upcoding due to ignorance of the new rules.

Another thing found in this study was that hospitals might argue differently from BPJS Health verifiers. In some cases, according to the informant, there were

Table 2. Percentage of Upcoding based on Casemix Main Group

\begin{tabular}{lcccl}
\hline Variable & $\begin{array}{c}\text { Casemix } \\
\text { Main Group }\end{array}$ & Total & $\%$ & Explanation \\
\hline Upcoding & O & 10 & 2,8 & Deliveries Group \\
$(43)$ & W & 6 & 1,7 & Female reproductive system Groups \\
& P & 4 & 1,1 & Newborns \& Neonates Groups \\
& K & 4 & 1,1 & Digestive system Group \\
G & 3 & 0,8 & Central nervous system Groups \\
& I & 3 & 0,8 & Cardiovascular system Groups \\
L & 3 & 0,8 & Skin, subcutaneous tissue \& breast Group \\
M & 3 & 0,8 & Musculoskeletal system \& connective tissue Groups \\
& D & 2 & 0,5 & Haemopoeitic \& immune system Groups \\
& C & 1 & 0,3 & Myeloproliferative system \& neoplasms Groups \\
& E & 1 & 0,3 & Endocrine system, nutrition \& metabolism Groups \\
& J & 1 & 0,3 & Respiratory system Groups \\
& N & 1 & 0,3 & Nephro-urinary System Groups \\
& U & 1 & 0,3 & Ear, nose, mouth \& throat Groups \\
\hline
\end{tabular}

Source: Primary Data

Table 3. Losses due to Upcoding

\begin{tabular}{lll}
\hline $\begin{array}{l}\text { (a) Total Hospital Revenue } \\
\text { from the Total Sample (IDR) }\end{array}$ & $\begin{array}{l}\text { coding Cases } \\
\text { codo Up }\end{array}$ & $\begin{array}{l}\text { Percentage of Loss due to Up coding } \\
\text { cases (\%) (b/c) } \times 100 \%\end{array}$ \\
\hline $1.721 .453 .800,00$ & $154.626 .000,00$ & $9 \%$ \\
\hline
\end{tabular}

Source: Primary Data 
files that were suspended by the Health BPJS because according to the verifier the diagnosis or procedure could not be claimed. The hospital actually had the right to answer this matter. There were several teams that could be consulted for coding disagreements between hospitals and BPJS Health, such as the coding consideration team, clinical consideration team, anti-fraud team from the District / City and Provincial Health Offices, and the Cost Control and Quality Control Team. But in practice the decision of the coding consideration team, for example, did not have permanent legal force, meaning that it was not absolutely a decision of the difference in understanding. This study also found that the hospital did not know the flow of coordination between the teams formed to resolve the problem of coding disagreement between the hospital and BPJS Health. The intended coordination flow was about which team that had the first role to solve the coding problem, and the next flow.

Another factor of upcoding is the doctor factor. According to the informant, doctors often did not know the coding rules. In the doctor's opinion, the symptoms of the disease could also be included in medical coding, when in fact it could not. In addition, the coders sometimes had difficulty reading unclear doctor's handwriting and abbreviations that were not understood. This could actually be bridged by the presence of general practitioners as internal verifiers of hospitals. However, in reality, not all hospitals had general practitioners as internal verifiers. In hospitals that did not have general practitioners as internal verifiers, the coder claimed to have often experienced miscommunication with specialist doctors.

Another cause of upcoding from the coder side was the lack of coder knowledge on the latest Ministry of Health regulations on medical coding. The coders who often participated in training felt a better understanding than just reading the Minister of Health regulations. However, the problem was that not all hospitals allowed coders to take part in training outside the city. This was also related to the low number of coders in the hospital, so that if the coders attended training, the service would be disrupted.

\section{DISCUSSION}

The upcoding cases in found this study were higher than those found in Germany and Australia. In Germany, upcoding occurred in $1 \%$ of inpatient payments (Lungen and Lauterbach, 2000), whereas in Australia, coding audits conducted in 1995-1996 showed that medical records containing upcoding were $5.2 \%$ while downcoding were $6.5 \%$ (Victoria State Government, 1997).

According to Steinbusch et al (2007), who examined casemix systems in USA, Australia and the Netherlands, upcoding was influenced by: 1) market characteristics (profit-making hospitals, hospital size, and financial situation), 2) characteristics of control systems (internal and external control mechanisms), 3) characteristics of casemix system (ambiguous classification criteria, time of first registration, coder incentives, and possibility to change the code after first registration (Steinbusch et al., 2007).

Upcoding itself can be categorized into three criteria. First, the coders explore the discharge summary and retrieve the best code. This new code can be obtained by exchanging primary and secondary diagnoses. (Steinbusch et al., 2007, Serdén et al., 2003). This can be done with computer software (Korcok, 1984). Hospitals can claim that the code change is in anticipation of under-reimbursement of the doctor's non-specificity in writing disease narratives. (Hsia et al., 1992). This type of code manipulation can only be done if the process of coding the disease is done after the patient goes home, such as the casemix system in the United States and Australia. Second, hospital coders can skip discharge summary and look for conditions that can be reimbursed in the patient's medical record. This is known as 
the DRG Bracket Creep, which is known as "benign" in upcoding (Silverman and Skinner, 2004). The most extreme form of upcoding is a in the form of manipulation by exaggerating the code without any supporting evidence in the medical record. The patient's condition can be made more severe by adding a secondary diagnosis (Serdén et al., 2003).

The results showed that the upcoding incidents that occurred in the hospitals in West Sumatra province were more common due to accidental factors, such as system weaknesses and human error. The absence of definite coding guidelines, the absence of internal verifier of a doctor in hospital, the unclear coordination flow of the team in charge of solving the coding problem between the hospital and BPJS Health, the lack of knowledge of doctors and coders about the latest coding rules, and the minimal number of coders in the hospital were the root causes of upcoding incidents.

Therefore, the approach in preventing upcoding, which is categorized as fraud in Minister of Health Regulation (PMK) No. 36 of 2015, using pattern of punishment is not appropriate. It would be better if the root of the upcoding problem is solved first so that the hospital can do the medical coding correctly and accurately.

\section{CONCLUSION}

More than one tenth of the medical record contains upcoding. The root of the upcoding problem is due to the absence of definite upcoding guidelines, ignorance of coders and doctors, and the minimal number of internal verifiers of doctors and coders in hospitals.

It is recommended that the Ministry of Health issue clear coding and upcoding rules. In addition, it is also recommended that hospitals conduct coding training on doctors and coders routinely, increase the number of internal doctors verifiers, and increase the number of coders.

\section{REFERENCES}

Barros, P. \& Braun, G. 2016. Upcoding In A National Health Service: The Evidence From Portugal. Health Economics.

BPJS 2016a. Laporan Pengelolaan Program Tahun 2016 Dan Laporan Keuangan 2016 (Auditan).

Hsia, D. C., Ahern, C. A., Ritchie, B. P., Moscoe, L. M. \& Krushat, W. M. 1992. Medicare Reimbursement Accuracy Under The Prospective Payment System, 1985 To 1988. Jama, 268, 896-899.

KEMENKES, R. 2004. UU NO. 40 Tahun 2004. Jakarta.

KEMENKES RI 2015a. Peraturan Menteri Kesehatan Republik Indonesia Nomor 36 Tahun 2015 Tentang Pencegahan Kecurangan (Fraud) Dalam Pelaksanaan Program Jaminan Kesehatan Pada Sistem Jaminan Sosial Nasional In: Ri, K. K. (Ed.). Jakarta: Kementerian Kesehatan Ri.

KEMENKES RI 2015b. Pmk No. 36 Tahun 2015 Tentang Pencegahan Kecurangan (Fraud) Dalam Pelaksanaan Program Jaminan Kesehatan Pada Sistem Jaminan Sosial Nasional. In: Ri, K. K. (Ed.). Jakarta: Kementerian Kesehatan Ri.

KEMENKES RI 2016a. Petunjuk Teknis Aplikasi Ina-Cbg V5 Kementerian Kesehatan Republik Indonesia Pusat Pembiayaan Dan Jaminan Kesehatan National Casemix Center, Jakarta, Kemenkes Ri.

Korcok, M. 1984. Will Drg Payments Creep Into All Us Health Insurance Plans? Canadian Medical Association Journal, 130, 912.

Lungen, M. \& Lauterbach, K. 2000. Upcoding--A Risk For The Use Of Diagnosis Related Group. Dtsch Med Wochenschr, 125, 852-6. 
Asia Pacific Fraud Journal, 5(1) January-June 2020: 56-61 | 61

Serdén, L., Lindqvist, R. \& Rosén, M. Steinbusch, P. J., Oostenbrink, J. B., 2003. Have Drg-Based Prospective Payment Systems Influenced The Number Of Secondary Diagnoses In Health Care Administrative Data? Health Policy, 65, 101-107.

Silverman, E. \& Skinner, J. 2004. Medicare Upcoding And Hospital Ownership. Journal Of Health Economics, 23, 369389.

Zuurbier, J. J. \& Schaepkens, F. J. 2007. The Risk Of Upcoding In Casemix Systems: A Comparative Study. Health Policy, 81, 289-299.

Victoria State Government 1997. Victoria, Public Hospitals, Policy And Funding Guidelines 1997-1998. Melbourne: Victoria State Government Departement Of Health. 